\title{
Upaya Meningkatkan Hasil Belajar Pkn Melalui Metode Jigsaw Siswa Kelas VI A SD Negeri 64/IV Kota Jambi Semester Ganjil Tahun Pelajaran 2016/2017
}

\author{
Aziar ${ }^{1}$ \\ ${ }^{1}$ Guru SD Negeri 64/IV Kota Jambi \\ Correspondence email: aziarjambi@gmail.com
}

\begin{abstract}
This research is motivated by the fact that students are less active in the class and the learning model used is not appropriate so that the results obtained are not maximal. The low learning outcomes of students in PKn subjects are thought to be caused by a mismatch of learning methods used by teachers in PKN learning. The lecture method commonly used by teachers in teaching is one-way learning, so it tends to make students become passive in learning. The research objectives to be achieved in this study are to improve the PKn learning process so that learning outcomes increase by applying the Jigsaw model of class VI.A Negeri SD 64 / IV Jambi City. This study uses action research as much as two cycles. Each cycle consists of four stages, namely: design, activity and observation, reflection, and revision. The target of this study was class VI A 64 / IV SD Negeri Jambi City. Data obtained in the form of the results of teacher learning management, and student learning outcomes. From the results of the analysis it was found that student learning outcomes experienced an increase from cycle I to cycle II. The Jigsaw model can improve the quality of learning Civics and Jigsaw Model has a positive impact on improving student learning outcomes which is characterized by an increase in student learning completeness in each cycle, namely pre cycle (50.00\%), cycle I (65.00\%), sklus II (85.00\%). The average value of learning outcomes in the first cycle is 71.72 and the second cycle increases to 80.77 . While for the management of teacher learning in the first cycle only reached $44.64 \%$ and the second cycle increased to $86.61 \%$, and the Jigsaw learning model could be used as an alternative to PKn learning.
\end{abstract}

Keywords: improvement, learning outcomes; jigsaw method

\section{PENDAHULUAN}

Pendidikan merupakan suatu usaha untuk mengembangkan dan membina potensi sumber daya manusia (SDM) melalui kegiatan belajar mengajar yang diselenggarakan pada semua jenjang pendidikan di tingkat dasar, menegah dan perguruan tinggi. Pendidikan disekolah mempunyai tujuan untuk mengubah pelajar atau siswa agar dapat memiliki pengetahuan keterampilan dan sikap pelajar sebagai bentuk perilaku hasil belajar. Perubahan dari hal ini biasanya dilakukan oleh guru dengan menggunakan beberapa metode dan kegiatan praktek untuk menunjang kegiatan proses belajar mengajar. Pada hakekatnya mata pelajaran PKn merupakan salah satu mata pelajaran yang wajib diajarkan disetiap jenjang pendidikan, karena berfungsi untuk mengembangkan sikap dan nilai moral, serta bertujuan untuk memberikan 2 pengalaman kepada siswa dalam merencanakan dan menerapkan sikap yang baik untuk membentuk moral dan watak yang baik pula.

Hasil belajar siswa dianalisis dengan menggunakan kriteria belajar minimal yang ditetapkan dalam kurikulum K13 yang berlaku di SD Negeri 64/IV Kota Jambi, yakni siswa dinyatakan tuntas belajar secara individu bila telah memperoleh skor $\geq 75 \%$ dari Skor total, dan tuntas secara klasikal tercapai bila dikelas tersebut terdapat $\geq 80 \%$ siswa tuntas belajar. Kenyataan yang ada menunjukkan bahwa hasil belajar siswa khususnya mata pelajaran PKn kelas VI SD Negeri 64/IV Kota Jambi tidak dapat dikatakan tuntas dalam pembelajaran karena tidak mencapai sesuai apa yang telah ditentukan. Ini berarti bahwa hasil belajar siswa pada mata pelajaran PKn masih perlu ditingkatkan. Rendahnya hasil belajar siswa pada mata pelajaran PKn mendorong penulis untuk melakukan penelitian tindakan kelas (PTK) sehingga tercapai tujuan yang diinginkan yakni peningkatan hasil belajar siswa kelas VI SD Negeri 64/IV Kota Jmabi pada mata pelajaran PKn. Penelitian tindakan kelas (PTK) adalah bentuk penelitian yang bersifat efektif dengan melakukan tindakan-tindakan tertentu agar dapat memperbaiki dan meningkatkan praktik-praktik pembelajaran secara profesional. Peningkatan hasil belajar dapat dilakukan apabila seorang guru menggunakan model pembelajaran yang tepat, salah satu dari model pembelajaran tersebut adalah Pembelajaran kooperatif tipe Jigsaw. Berdasarkan hasil observasi serta hasil wawancara dengan salah satu guru kelas yang mengajarkan PKn di SD Negeri 64/IV Kota Jambi, dalam pembelajaran di sekolah. Siswa kurang aktif dalam kelas dan model pembelajaran yang digunakan kurang tepat sehingga hasil yang diperoleh kurang maksimal. Olehnya itu, peneliti mencoba menerapkan Pembelajaran Kooperatif Tipe Jigsaw, agar siswa bisa lebih aktif dalam kegiatan pembelajaran sehingga guru dapat mengetahui seberapa jauh peningkatan hasil belajar siswa kelas $\mathrm{VI}$ pada mata pelajaran PKn di SD Negeri 64/IV Kota Jambi.

Dalam proses belajar-mengajar, guru harus memiliki strategi, agar peserta didik dapat belajar secara efektif, efisien, dan tepat pada tujuan yang diharapkan. Satu di antara langkah untuk memiliki strategi itu ialah harus menguasai teknik-teknik penyajian, atau biasa disebut dengan metode mengajar atau model pembelajaran.

Menurut Rusman (2012, 133) Model pembelajaran adalah suatu rencana atau pola yang dapat digunakan untuk membentuk kurikulum(rencana pembe-lajaran jangka panjang), merancang bahanbahan pembelajaran dan mem-bimbing pembelajran di kelas yang lain.

Rendahnya hasil belajar peserta didik pada mata pelajaran PKN ini diduga disebabkan oleh ketidaksesuaian metode pembelajaran yang digunakan guru dalam pembelajaran PKN. Metode ceramah yang biasa digunakan guru dalam mengajar merupakan 
pembelajaran satu arah, sehingga cenderung membuat peserta didik menjadi pasif dalam belajar. Oleh karena itu guru dituntut untuk memahami dan menempatkan beragam metode pembelajaran agar peserta didik aktif dalam belajar.

Salah satunya metode yang tepat dalam pembelajaran PKN model pembelajaran kooperatif dengan menggunakan metode Jigsaw. Model pembelajaran kooperatif adalah kegiatan pembelajaran dengan cara berkelompok unutk bekerja sama saling membantu mengkonstruksi konsep, meyelesaikan persoalan atau inkuiri (Effendi, 2010:108). Pembelajaran kooperatif merupakan salah satu model pembelajaran kelompok yang memiliki atura-aturan tertentu, dimana peserta didik membentuk kelompok kecil dan saling mmengajar sesamanya unutk mencapai tujuan bersama (Wena, 2012: 189). Model Jigsaw adalah sebuah metode belajar kooperatif yang menitik beratkan pada kerja kelompok peserta didik dalam bentuk kelompok kecil. Jigsaw merupakan salah satu tipe atau model pembelajaran kooperatif yang fleksibel. (Rusman, 2012:217).

\section{Tinjauan Pustaka \\ Hakikat Belajar}

Belajar adalah suatu aktivitas atau suatu proses untuk memperoleh pengetahuan, meningkatkan keterampilan memperbaiki perilaku sikap dan mengkokohkan kepribadian (Suryono Hariyanto. 2012: 19). "Belajar merupakan komponen paling vital dalam setiap usaha penyelenggaraan jenis dan jenjang pendidikan, sehingga tanpa proses belajar sesungguhnya tidak pernah ada pendidikan" (Sagala, 2010:13).

Menurut Hamalik (2009:28), belajar adalah suatu proses perubahan tingkah laku melalui interaksi antara individu dan lingkungan. Proses dalam hal ini, merupakan urutan kegiatan yang berkesinambungan, bertahap, bergilir, dan terpadu yang secara keseluruhan mewarnai dan memberikan karakteristik terhadap belajar itu.

Belajar merupakan tindakan dan perilaku yang kompleks, sebagai tindakan belajar yang dialami oleh peserta didik sendiri. Dimyati dan Mujiono (dalam Sagala, 2010:13) mengemukakan peserta didik adalah penentu terjadinya atau tidak terjadinya proses belajar. Menurut Gagne (dalam Sagala, 2010:17) belajar adalah seperangkat proses kognitif yang mengubah sifat stimulasi lingkungan, melewati pengolahan informasi, menjadi kapabilitas baru. Belajar terjadi apabila ada hasil yang diperlihatkan, anak-anak maupun orang dewasa dapat mengingat kembali kata-kata yang pernah didengar atau dipelajari.

Menurut Piaget (dalam Sagala, 2010:29) belajar mengandung makna sebagai perubahan struktural yang saling melengkapi antara asimilasi dan akomodasi dalam proses menyusun kembali dan mengubah apa yang telah diketahui melalui belajar. Menurut Slameto (2003:2) belajar adalah suatu proses usaha yang dilakukan seseorang untuk memperoleh suatu perubahan tingkah laku yang baru, secara keseluruhan sebagai hasil pengalamannya sendiri dalam interaksi dengan lingkungannya.
Menurut Slameto (2003:54), terdapat dua faktor yang mempengaruhi proses belajar yaitu :

\section{Faktor Intern}

Faktor-faktor intern yang berpengaruh terhadap belajar terdiri atas tiga faktor yaitu:

a. Faktor jasmani. Yang meliputi faktor kesehatan, proses belajar seseorang akan terganggu jika kesehatan seseorang terganggu, mudah pusing, ngantuk jika bandannya lemah, dan kelainankelainan fungsi alat inderanya serta tubuhnya. Faktor cacat tubuh adalah sesuatu yang menyebabkan kurang baik atau kurang sempurna mengenai tubuh atau badan.

b. Faktor psikologis. Faktor-faktor itu antara lain adalah : intelegensi, perhatian, minat, bakat, motif, kematangan dan kelelahan.

c. Faktor kelelahan. Agar peserta didik dapat belajar dengan baik haruslah menghindari agar jangan sampai terjadi kelelahan dalam belajarnya.

\section{Faktor Ekstern.}

Faktor-faktor ekstern yang berpengaruh terhadap belajar terdiri atas tiga faktor yaitu:

a. Faktor keluarga. Peserta didik yang belajar akan menerima pengaruh dari keluarga berupa cara orang tua mendidik, relasi antara anggota keluarga, suasana rumah tangga dan keadaan ekonomi.

b. Faktor sosial. Faktor sekolah yang mempengaruhi belajar ini mencakup metode mengajar, kurikulum, relasi guru dengan peserta didik, pelajaran dengan waktu sekolah, standar pelajaran, keadaan gedung, metode belajar dan tugas rumah.

c. Faktor masyarakat. Pengaruh ini terjadi karena keberadaannya peserta didik dalam masyarakat.

Dari pendapat di atas, dapat disimpulkan bahwa belajar merupakan suatu proses perubahan tingkah laku dan penambahan pengetahuan berdasarkan hasil dari interaksi dengan lingkungannya dan dari pengalaman tertentu.

\section{Hakikat Hasil Belajar}

Hasil belajar merupakan hasil yang dapat dipandang dari dua sisi yaitu : dari sisi peserta didik dan dari sisi guru. Dari sisi peserta didik, hasil belajar merupakan tingkat perkembangan mental yang lebih baik bila dibandingkan pada saat sebelum belajar. Tingkat perkembangan mental tersebut terwujud pada jenis-jenis ranah kognitif, afektif, dan psikomotorik. Sedangkan dari sisi guru, hasil belajar merupakan saat terselesaikannya bahan pelajaran.

Hasil belajar adalah kemampuan-kemampuan yang dimiliki peserta didik setelah ia menerima pengalaman belajarnya yakni keterampilan dan kebiasaan, pengetahuan dan pengertian, sikap dan citacita (Sudjana Nana. 2009 :22).

Menurut Nana Sudjana, (2002: 22) hasil belajar dibagi menjadi tiga macam yaitu: a) Keterampilan dan kebiasaan; b) Pengetahuan dan pengertian; c) Sikap dan citacita, yang masing-masing golongan dapat diisi dengan bahan yang ada pada kurikulum sekolah. Menurut Gagne dalam Marlina, (2010: 12) terdapat lima macam hasil belajar, tiga yang pertama bersifat kognitif, 
yang keempat bersifat afektif dan yang kelima bersifat psikomotorik.

Menurut Abdurrahman, (2009:37) Hasil belajar adalah kemampuan yang diperoleh anak setelah melalui kegiatan belajar. Menurut Sudjana (2006:22) hasil belajar adalah kemampuan-kemampuan yang dimiliki peserta didik setelah ia menerima pengalaman belajarnya. Dalam sistem pendidikan nasional rumusan tujuan pendidikan, baik tujuan kurikuler maupun tujuan instruksional, menggunakan klasifikasi hasil belajar dari Benjamin S. Bloom yang secara garis besar membagi menjadi tiga ranah, yaitu :

1. Ranah Kognitif berkenaan dengan hasil belajar intelektual.

2. Ranah Afektif berkenaan dengan sikap.

3. Ranah Psikomotoris berkenaan dengan hasil belajar keterampilan dan kemampuan bertindak.

Menurut A. J. Romiszowki (dalam Abdurrahman 2009:38) hasil belajar merupakan keluaran (outputs) dari suatu system pemrosesan masukan (inputs). Masukan dari sistem tersebut berupa bermacam-macam informasi sedangkan keluarannya adalah perbuatan atau kinerja (performance). Menurut Keller (dalam Abdurrahman 2009:39) hasil belajar adalah prestasi aktual yang ditampilkan oleh anak, sedangkan usaha adalah perbuatan terarah pada penyelesaian tugas-tugas belajar. Menurut Sumarso (2009) "hasil belajar merupakan segala sesuatu yang diperoleh, dikuasai atau merupakan hasil proses belajar mengajar. Hasil belajar merupakan kemampuan yang dimiliki peserta didik setelah ia menerima pengalaman belajar".

Untuk mencapai hasil belajar tersebut banyak faktor yang mempengaruhinya. Menurut Sumarso, faktor yang mempengaruhi hasil belajar peserta didik dapat digolongkan menjadi :

1. Faktor internal (dalam diri peserta didik) yakni keadaan/kondisi jasmani (fisiologis) dan rohani (aspek psikologis) seperti tingkat kecerdasan/intelegensi peserta didik, sikap peserta didik, bakat peserta didik, minat peserta didik, motivasi peserta didik.

2. Faktor eksternal (dari luar diri peserta didik), yakni kondisi lingkungan di sekitar peserta didik, terdiri dari dua macam yaitu faktor lingkungan sosial dan lingkungan non sosial.

3. Faktor pendekatan belajar (approach to learning), yakni jenis upaya belajar peserta didik yang meliputi strategi dan metode yang digunakan peserta didik untuk melakukan kegiatan pembelajaran materimateri pembelajaran.

Menurut Gagne dalam Agus ( 2012 :6) hasil belajar berupa:

1. Informasi verbal yang kapabilitas yang mengungkapkan pengetahuan daam bentuk bahasa, baik lisan maupun tertulis.

2. Kemampuan intelektual yaitu kemampuan mempresentasikan konsep dan lambang.Kemampuan intelektual terdiri dari kemampuan mengkategorisasikan, kemampuan analitis sintesis fakta konsep dan mengembangkan prnsip-prinsip keilmuan.

3. Strategi kognitif yaitu kecakapan menyalurkan dan mengarahkan aktivitas kognitifnya sendiri, kemampuan ini meliputi penggunaan konsep dan kaidah dalam memecahkan masalah.

4. Keterampilan motorik yaitu emampuan melakukan serangkaian gerak jasmani dalam urusan dan koordinasi sehingga terwujud otomatisme gerak jasmani.

5. Sikap. Adalah kemampuan menerima atau menolak objek berdasarkan penilaian terhadap objek tersebut.

Dari beberapa pendapat di atas dapat disimpulkan bahwa hasil belajar adalah suatu tingkat keberhasilan (prestasi) peserta didik dalam proses belajar mengajar untuk memenuhi suatu tahapan pencapaian pengalaman belajar dalam satu kompetensi dasar yang diperoleh dari tes dan dinyatakan dalam bentuk skor.

\section{Hakikat Pembelajaran}

Pembelajaran merupakan proses komunikasi dua arah, mengajar dilakukan oleh pihak guru sebagai pendidik, sedangkan belajar dilakukan oleh peserta didik atau murid. Sering dikatakan mengajar adalah mengorganisasikan aktivitas peserta didik dalam arti luas. Pembelajaran mengandung arti setiap kegiatan yang dirancang untuk membantu seseorang mempelajari suatu kemampuan dan atau nilai yang baru (Sagala 2010:61). Pembelajaran menurut Dimyati dan Mudjiono (dalam Sagala 2010:62) adalah kegiatan guru secara terprogram dalam desain instruksional, untuk membuat peserta didik belajar secara aktif, yang menekankan pada penyediaan sumber belajar.

Undang-undang Sistem Pendidikan Nasional No. 20 tahun 2003 (dalam Sagala 2010:62) menyatakan pembelajaran adalah proses interaksi peserta didik dengan pendidik dan sumber belajar pada suatu lingkungan belajar. "Pembelajaran adalah suatu kombinasi yang tersusun meliputi unsur-unsur manusiawi, material, fasilitas, perlengkapan, dan prosedur yang saling mempengaruhi mencapai tujuan pembelajaran" (Hamalik 2001: 57).

Menurut (Hamalik, 2009: 65-66) ada tiga ciri khas yang terkandung dalam sistem pembelajaran, yaitu:

1. Rencana: penataan ketenagaan, material dan prosedur yang merupakan unsur-unsur sistem pembelajaran, dalam suatu rencana khusus.

2. Kesalingtergantungan antara unsur-unsur sistem pembelajaran yang serasi dalam suatu keseluruhan

3. Tujuan dari sistem pembelajaran yang hendak dicapai.

Dari pendapat-pendapat di atas dapat disimpulkan bahwa pembelajaran adalah suatu suatu interaksi/kegiatan yang terjadi antara pendidik dengan peserta didik yang bertujuan untuk membuat peserta didik aktif dan memberi pengetahuan kepada peserta didik.

\section{Model Pembelajaran}

"Model dapat diartikan sebagai kerangka konseptual yang digunakan sebagai pedoman dalam melakukan kegiatan" (Sagala, 2010:175). "Model pembelajaran dapat diartikan sebagai kerangka konseptual yang mendeskripsikan dan melukiskan prosedur yang sistematik dalam mengorganisasikan pengalaman belajar dan pembelajaran untuk mencapai tujuan belajar tertentu, dan berfungsi sebagai pedoman 
bagi perencanaan pengajaran bagi para guru dalam melaksanakan aktivitas pembelajaran" (Sagala, 2010:176).

Menurut Joyce dan Weil (dalam Sagala 2010:176) model pembelajaran adalah suatu deskripsi dari lingkungan yang menggambarkan perencanaan kurikulum, kursus-kursus, desain unit-unit pelajaran dan pembelajaran, perlengkapan belajar, buku-buku pelajaran, program multimedia, dan bantuan belajar melalui program komputer. Sebab model-model ini menyediakan alat-alat belajar bagi para peserta didik.

Menurut Trianto (dalam Gunawan 2010) model pembelajaran adalah kerangka konseptual yang melukiskan prosedur yang sistematis dalam mengorganisasikan pengalaman belajar untuk mencapai tujuan belajar tertentu, dan berfungsi pedoman bagi para perancang pembelajaran dan para pengajar dalam merencanakan aktivitas belajar mengajar. Sedangkan menurut Wahab (2008:78), "model pembelajaran adalah sebuah perencanaan pengajaran yang mengembangkan proses yang akan ditempuh dalam proses belajarmengajar agar dicapai prilaku seperti yang diharapkan".

Wahab (2008:54) mengungkapkan, pada umumnya model-model pembelajaran yang baik memiliki sifat-sifat atau ciri-ciri yang dapat dikenali secara umum sebagai berikut:

1. Memiliki prosedur yang sistematik.

2. Hasil belajar ditetapkan secara khusus.

3. Penetapan lingkungan secara khusus.

4. Ukuran keberhasilan.

5. Interaksi dengan lingkungan.

Beberapa fungsi secara khusus dari sebuah model pengajaran, seperti yang diutarakan oleh SS Chauhan (dalam Wahab, 2008:55) adalah sebagai berikut :

1. Pedoman, model mengajar berfungsi sebagai pedoman yang dapat menjelaskan apa yang harus dilakukan guru. Pengembangan kurikulum, model pembelajaran dapat membantu dalam pengembangan kurikulum untuk satuan dan kelas yang berbeda dalam pendidikan.

2. Menetapkan bahan-bahan pengajaran, model belajar menetapkan secara rinci bentuk-bentuk bahan pengajaran yang berbeda yang akan digunakan guru dalam membantu perubahan yang baik dari kepribadian peserta didik.

3. Membantu perbaikan dalam mengajar, model mengajar dapat membantu proses mengajar-belajar dan meningkatkan keefektifan mengajar.

Dari pendapat-pendapat di atas dapat disimpulkan bahwa model pembelajaran merupakan suatu perencanaan pengajaran sebagai pedoman guru yang menggambarkan proses kegiatan belajar mengajar untuk mencapai tujuan belajar tertentu.

\section{Pembelajaran Kooperatif (Cooperative Learning)}

Pembelajaran kooperatif (Cooperative Learning) merupakan suatu model pembelajaran dimana peserta didik belajar dalam kelompok-kelompok kecil yang memiliki tingkat kemampuan yang berbeda (Ibrahim 2009:11).

Menurut Lie pembelajaran kooperatif adalah sistem pengajaran yang memberikan kesempatan kepada peserta didik untuk berkerjasama sesama peserta didik dalam tugas-tugas berstruktur. Dipihak lain menurut Slavin pembelajaran kooperatif adalah suatu model pembelajaran dimana peserta didik belajar dan bekerja dalam kelompok-kelompok kecil secara kolaboratif yang anggotanya terdiri dari 3 sampai 5 orang, dengan struktur kelompok yang bersifat heterogen.

Menurut Slavin (dalam Trianto, 2010:61) ada tiga konsep utama belajar kooperatif yang membedakan dengan model pembelajaran yang lainya, yaitu :

1. Penghargaan kelompok.

2. Tanggung jawab individual.

3. Kesempatan yang sama untuk sukses.

Arends (dalam Trianto, 2010:65-66) menyatakan bahwa pelajaran yang menggunakan pembelajaran kooperatif memiliki ciri-ciri sebagai berikut :

1. Peserta didik bekerja dalam kelompok secara kooperatif untuk menuntaskan materi belajar.

2. Kelompok dibentuk dari peserta didik yang mempunyai kemampuan tinggi, sedang, dan rendah.

3. Bila memungkinkan, anggota kelompok berasal dari ras, budaya, suku, jenis kelamin yang beragam.

4. Penghargaan lebih berorientasi kepada kelompok dari pada individu.

Menurut Ibrahim (dalam Trianto, 2010:59) pada dasarnya pembelajaran kooperatif dikembangkan untuk mencapai setidak-tidaknya tiga tujuan pembelajaran penting, yaitu:

1. Hasil belajar akademik

Dalam pembelajaran kooperatif meskipun mencakup beragam tujuan sosial, juga memperbaiki prestasi peserta didik atau tugas-tugas akademis penting lainnya. Beberapa ahli berpendapat bahwa model ini unggul dalam membantu peserta didik memahami konsep-konsep sulit.

2. Penerimaan terhadap perbedaan individu

Tujuan lain model kooperatif adalah penerimaan secara luas dari orang-orang yang berbeda berdasarkan rasa, budaya, kelas sosial, kemampuan, dan ketidakmampunnya. Pembelajaran kooperatif memberi peluang bagi peserta didik dari berbagai latar belakang dan kondisi untuk bekerja dengan saling bergantung pada tugas-tugas akademik dan melalui struktur penghargaan kooperatif akan belajar saling menghargai satu sama lain.

3. Pengembangan keterampilan sosial

Tujuan penting lainnya adalah mengajarkan kepada peserta didik keterampilan berkerja sama dan kolaborasi. Keterampilan-keterampilan sosial penting dimiliki peserta didik, sebab saat ini banyak anak muda masih kurang dalam keterampilan sosial.

\section{Pembelajaran Kooperatif Tipe Jigsaw}

Model Jigsaw adalah sebuah metode belajar kooperatif yang menitik beratkan pada kerja kelompok peserta didik dalam bentuk kelompok kecil. Jigsaw merupakan salah satu tipe atau model pembelajaran kooperatif yang fleksibel. (Rusman, 2013:217). Pembelajaran kooperatif tipe Jigsaw ini pertama kali dikembangkan oleh Aronson dalam Hisyam Zaini dkk, (2004: 23). Langkah-langkah mengaplikasikan tipe 
Jigsaw dalam proses pembelajaran adalah sebagai berikut:

1. Guru membagi suatu kelas menjadi beberapa kelompok, dengan setiap kelompok terdiri dari 4-6 siswa dengan kemampuan yang berbeda-beda baik tingkat kemampuan tinggi, sedang, dan rendah serta jika mungkin anggota berasal dari ras, budaya, suku yang berbeda tetapi tetap mengutamakan kesetaraan jender. Kelompok ini disebut kelompok asal. Jumlah anggota dalam kelompok asal menyesuaikan dengan jumlah bagian materi pelajaran yang akan dipelajari siswa sesuai dengan tujuan pembelajaran yang akan dicapai. Dalam tipe Jigsaw ini, setiap siswa diberi tugas mempelajari salah satu bagian materi pembelajaran tersebut. Semua siswa dengan materi pembelajaran yang sama belajar bersama dalam kelompok yang disebut kelompok ahli (Counterpart Group/CG).

2. Dalam kelompok ahli, siswa mendiskusikan bagian materi pembelajaran yang sama, serta menyusun rencana bagaimana menyampaikan kepada temannya jika kembali ke kelompok asal. Kelompok asal ini oleh Aronson disebut kelompok jigsaw (gigi gergaji).

3. Misal suatu kelas dengan jumlah siswa 32, dan materi pembelajaran yang dicapai sesuai dengan tujuan pembelajarannya terdiri dari 5 bagian materi pembelajaran, maka dari 32 siswa akan terdapat 5 kelompok ahli yang beranggotakan 5 siswa dan 6 kelompok asal yang terdiri dari 5 siswa. Setiap anggota kelompok ahli akan kembali ke kelompok asal memberikan informasi yang telah diperoleh dalam diskusi di kelompok ahli dan setiap siswa menyampaikan apa yang telah diperoleh atau dipelajari dalam kelompok ahli. Guru memfasilitasi diskusi kelompok baik yang dilakukan oleh kelompok ahli maupun kelompok asal.

4. Setelah siswa berdiskusi dalam kelompok ahli maupun kelompok asal, selanjutnya dilakukan presentasi masing-masing kelompok atau dilakukan pengundian salah satu kelompok untuk menyajikan hasil diskusi kelompok yang telah dilakukan agar guru dapat menyamakan persepsi pada materi pembelajaran yang telah didiskusikan.

5. Guru memberikan kuis untuk siswa secara individual. 5

6. Guru memberikan penghargaan pada kelompok melalui skor penghargaan berdasarkan perolehan nilai peningkatan hasil belajar individual dari skor dasar ke skor kuis berikutnya (terkini).

7. Materi sebaiknya secara alami dapat dibagi menjadi beberapa bagian materi pembelajaran.

8. Perlu diperhatikan bahwa jika menggunakan tipe Jigsaw untuk belajar materi baru, perlu dipersiapkan suatu tuntunan dan isi materi yang runtut serta cukup sehingga tujuan pembelajaran dapat tercapai. Strategi ini merupakan strategi yang menarik untuk digunakan jika materi yang akan dipelajari dapat dibagi menjadi beberapa bagian dan materi tersebut tidak mengharuskan urutan penyampaian. Kelebihan strategi ini adalah dapat melibatkan seluruh siswa dalam belajar dan sekaligus mengajarkannya kepada orang lain

\section{METODE PENELITIAN Jenis Penelitian}

Penelitian ini merupakan penelitian tindakan kelas (classroom action research), karena penelitian dilakukan untuk memecahkan masalah pembelajaran di kelas. Penelitian ini juga termasuk penelitian deskriptif, sebab menggambarkan bagaimana suatu teknik pembelajaran diterapkan dan bagaimana hasil yang diinginkan dapat dicapai.

Dalam penelitian ini menggunakan bentuk guru sebagai peneliti, dimana guru sangat berperan sekali dalam proses penelitian tindakan kelas. Dalam bentuk ini, tujuan utama penelitian tindakan kelas ialah untuk meningkatkan praktik-praktik pembelajaran di kelas. Dalam kegiatan ini, guru terlibat langsung secara penuh dalam proses perencanaan, tindakan, observasi, dan refleksi. Kehadiran pihak lain dalam penelitian ini peranannya tidak dominan dan sangat kecil.

\section{Lokasi dan Waktu Penelitian}

Lokasi penelitian tindakan kelas ini adalah SD Negeri 64/IV Kota Jambi. Penelitian ini dilakukan pada semester genap tahun pelajaran 2016/2017 yang berlokasi di Jalan Ir H Juanda Karta Wijaya Rt 33 simpang 3 sipin kecamatan Kota Baru Kota Jambi.

\section{Subjek Penelitian}

Subjek dalam penelitian ini adalah siswa kelas VI.A SD Negeri 64 Kecamatan Kota Baru sebanyak 38 orang yang terdiri dari 19 siswa laki-laki dan 19 siswa perempuan. Penelitian dilakukan di kelas VI.B karena peneliti adalah sebagai tenaga pengajar mata pelajaran PKn pada semester genap tahun pelajaran 2016/2017 dengan materi "Tokoh dan penemuan / Penemu yang mengubah dunia"

\section{Indikator Kinerja}

Indikator keberhasilan penelitian ini dengan menggunakan hasil nilai pembelajaran KKM 75 dan telah terjadinya peningkatan hasil belajar peserta didik terhadap pelajaran PKN

\section{Prosedur Penelitian}

Prosedur dan langkah-langkah penelitian yang digunakan mengikuti model yang dikembangkan oleh Kemmis dan Robin MC Taggart (Kusumah, W. 2009 : 21) yang berupa model spiral. Perencanaan Kemmis mengunakan system spiral refleksi diri yang dimulai dengan rencana, tindakan, pengamatan, refleksi, perencanaan kembali merupakan suatu dasar untuk memecahkan masalah. Langkah-langkah operasional penelitian meliputi tahap persiapan, perencanaan (planning), tindakan (acting), pengamatan (observing), refleksi (reflecting).

\section{Teknik Analisis Data Observasi}

Untuk menentukan nilai observasi terhadap aktifitas belajar peserta didik dinyatakan dengan kategori dan kriteria yang dapat dilihat pada tabel di bawah ini.

Untuk melihat persentase aktifitas peserta didik perkelompok digunakan rumus di bawah ini: 


$$
\%=\frac{\text { Jumlah deskriptor yang muncul pada tiap kelompok }}{\text { Jumlah total deskriptor yang muncul pada tiap kelompok }} \times 100 \%
$$

Dari data di atas, dapat diperoleh persentase aktivitas kelas, dengan menggunakan rumus:

$$
\%=\frac{\text { Jumlah persentase }}{\text { deskriptor yang muncul pada seluruh kelompok }} \times 100 \%
$$

\begin{tabular}{|c|c|}
\hline Nilai & Kategori nilai \\
\hline $81-100$ & Sangat baik \\
\hline $61-80$ & Baik \\
\hline $41-60$ & Cukup \\
\hline $21-40$ & Kurang \\
\hline$\leq 20$ & Sangat kurang \\
\hline
\end{tabular}

Tabel 1. Kategori Penilaian Keaktifan

(Sudjana, N. 2005:133)

\section{Tes}

Ketuntasan belajar peserta didik dapat dilihat dari sisi individual dan klasikal. Ketuntasan belajar individual tercapai bila peserta didik memperoleh skor $\geq$ KKM dan ketuntasan belajar secara klasikal tercapai jika kelas tersebut $85 \%$ peserta didik yang memperoleh skor $\geq$ KKM.

Tabel 2. Kategori Penilaian

\begin{tabular}{ll}
\hline \multicolumn{1}{c}{ Nilai } & \multicolumn{1}{c}{ Kategori nilai } \\
\hline $86-100$ & Sangat baik \\
$76-85$ & Baik \\
$60-75$ & Cukup \\
$55-59$ & Kurang \\
$\leq 54$ & Sangat kurang \\
\hline
\end{tabular}

(Purwanto, $2004:$ 103)

Untuk mengolah skor mentah menjadi nilai digunakan rumus sebagai berikut :

$S=\frac{R}{N} \times 100$

Keterangan :

$\mathrm{S}$ : Nilai persen yang dicari/diharapkan

$\mathrm{R}$ : Jumlah skor dari item soal yang dijawab benar

$\mathrm{N}$ : Skor maksimum dari tes yang bersangkutan

100 : Bilangan tetap

(Purwanto, 2004 : 112)
Untuk mencari nilai rata-rata ulangan harian digunakan rumus :

$\bar{X}=\frac{\sum x}{n}$

$\square \quad$ : Nilai rata-rata seluruh peserta didik

$\Sigma X$ : Jumlah seluruh nilai peserta didik

$\mathrm{n} \quad$ : Jumlah seluruh peserta didik

(Arikunto, 2005:264)

\section{HASIL DAN PEMBAHASAN \\ Pra Siklus}

Pra Siklus merupakan kondisi awal siswa sebelum peneliti melakukan kegiatan penelitian di dalam kelasdengan menggunakan pola pembelajaran konvensional atau Teacher Center. Selanjutnya berdasarkan hasil data Pra Siklus yang diperoleh peneliti bersama guru lain (Observer) melakukan evaluasi mengenai metode/model pembelajaran yang dianggap tepat, sebagai bentuk tindakan perbaikan dari proses pembelajaran.

Kegiatan pengambilan data Pra-Siklus dilakukan tanggal 22 Janauri 2017 Subjek Pra-siklus adalah siswa Kelas VI.A SD Negeri 64/IV Kota Jambi dengan jumlah 38 siswa. Pra-siklus dilakukan peneliti dengan cara melaksanakan kegiatan pembelajaran $\mathrm{PKn}$ dengan menggunakan metode ceramah yang diakhiri dengan pelaksanaan tes.

Hasilnya proses pembelajaran terlihat monoton dan berpusat pada guru. Selain itu, tingkat partisipasi siswa dalam belajar masih rendah terlihat dari kondisi siswa yang kurang bersemangat dalam belajar. Masih banyak siswa, yang tidak memperhatikan ketika guru menerangkan pelajaran di depan kelas, dengan cara mengobrol bersama antar teman-temannya.

Dampaknya prestasi hasil belajar siswa yang rendah, dibuktikan hasil (Pre-Test) dengan nilai tertinggi 80 , terendah 30, dan rata-rata 56.25 Data selengkapnya,

\begin{tabular}{|c|c|c|c|c|c|c|c|c|c|c|}
\hline \multirow[t]{2}{*}{ No } & \multirow[t]{2}{*}{ Nama } & \multicolumn{5}{|c|}{ Nomor Soal } & \multirow{2}{*}{ Jml Skor } & \multirow{2}{*}{ Daya Serap \% } & \multicolumn{2}{|c|}{ Ketuntasan } \\
\hline & & 1 & 2 & 3 & 4 & 5 & & & Ya & Tidak \\
\hline 1 & Alfaredho & 2 & 1 & 1 & 1 & 1 & 60 & $60 \%$ & & $\mathrm{v}$ \\
\hline 2 & Andi Raihan & 2 & 2 & 1.5 & 1 & 1 & 75 & $75 \%$ & $\mathrm{v}$ & \\
\hline 3 & Andreas Manik & 2 & $\overline{1}$ & 1 & 1 & 2 & 70 & $70 \%$ & & \\
\hline 4 & Audy Anggraini & 1 & 1 & 1.5 & 2 & 2 & 75 & $75 \%$ & v & \\
\hline 5 & Balqis Felisyalini & 2 & 1.5 & 1 & 1 & 1 & 65 & $65 \%$ & & v \\
\hline 6 & Benyamin.P & $\overline{1}$ & 1.5 & 1 & 1 & 2 & 65 & $65 \%$ & & v \\
\hline 7 & Dara Maya & 1 & 1 & 1 & 2 & 2 & 70 & $70 \%$ & & v \\
\hline 8 & Desta Bayu P. & 1 & 0 & 1 & $\overline{1}$ & 0 & 30 & $30 \%$ & & v \\
\hline 9 & Dini Andriani & 2 & 1 & 1 & 1 & 1 & 60 & $60 \%$ & & v \\
\hline 10 & Duwanti Maharani & 1 & 1 & 1 & 2 & 2 & 70 & $70 \%$ & & $\mathrm{v}$ \\
\hline 11 & Enji Avrilaysa & 1 & 1 & 1 & 1 & 1 & 50 & $50 \%$ & & $\mathrm{v}$ \\
\hline 12 & Izky Wardaniah & 1 & 2 & 2 & 2 & 1 & 80 & $80 \%$ & $\mathrm{v}$ & \\
\hline
\end{tabular}
dapat dilihat pada tabel dibawah ini:

Tabel 3. Hasil Analisis Tes Evaluasi Siswa Pra Siklus SD Negeri 64/IV Kota Jambi Tahun Pelajaran 2016/2017 
14 Julius Martinus

15 Kamila

16 Dwi Carel

17 M.Fadil Pratama

19 M.Rifki Januarda

20 Mafaza Karima

21 M.Rifky

22 M.Naufal

23 M.Valenzo

24 Nadia Rahmayanti

25 Puspita Indriani

26 Puti Jelita Zahara

28 S.M.Fadlan

29 Septi Yuliana

30 Shella Putri

31 Stepanus

32 Talitha

Jumlah Skor

Nilai Rata - Rata Perkelas
13 Josef Martinus

18 M.Febrian

27 Roro Refa

$\begin{array}{ccccc}2 & 1.5 & 1 & 1 & 2 \\ 1 & 1 & 1 & 2 & 1.5 \\ 1 & 1 & 0 & 1 & 1 \\ 1 & 1 & 1 & 1 & 1 \\ 2 & 2 & 1 & 0 & 0.5 \\ 1 & 0 & 1 & 1 & 1 \\ 1 & 1 & 1 & 2 & 1 \\ 1 & 1.5 & 1 & 2 & 2 \\ 1 & 1 & 1.5 & 2 & 2 \\ 2 & 2 & 1 & 1 & 2 \\ 1 & 2 & 2 & 1 & 2 \\ 1 & 2 & 1 & 2 & 1.5 \\ 1 & 1 & 1 & 1 & 1 \\ 2 & 1 & 1 & 2 & 2 \\ 2 & 1.5 & 1 & 1 & 1 \\ 1 & 1 & 2 & 2 & 2 \\ 1 & 0 & 1.5 & 1.5 & 2 \\ 1 & 1 & 1 & 1 & 1 \\ 2 & 2 & 1 & 1 & 1.5 \\ 2 & 1.5 & 2 & 1 & 1\end{array}$

2
1.5
1
1
0.5
1
1
2
2
2
2
1.5
1
2
1
2
2
1
1.5
1

5

1

0.5

2

2

2

1.5

1

1

.5

1

75
65
40
50
45
40
50
75
75
80
80
75
50
75
75
80
60
50
75
75
2060
64.36

\begin{tabular}{l}
$75 \%$ \\
$65 \%$ \\
$40 \%$ \\
$50 \%$ \\
$45 \%$ \\
$40 \%$ \\
$50 \%$ \\
$75 \%$ \\
$75 \%$ \\
$80 \%$ \\
$80 \%$ \\
$75 \%$ \\
$50 \%$ \\
$75 \%$ \\
$75 \%$ \\
$80 \%$ \\
$60 \%$ \\
$50 \%$ \\
$75 \%$ \\
$75 \%$ \\
\hline \\
Cukup
\end{tabular}
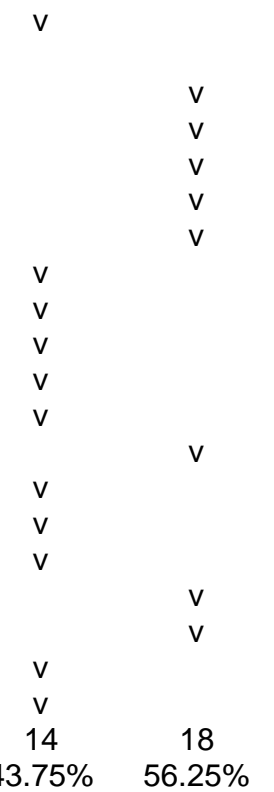

Dari tabel di atas dapat dijelaskan bahwa sebelum menerapkan model pembelajaran Jigsaw diperoleh nilai rata-rata hasil belajar siswa adalah 64,36 dengan persentase ketuntasan belajar mencapai $43.75 \%$ atau ada 14 siswa dari 32 siswa yang tuntas belajar.

Hasil tersebut menunjukkan bahwa pada pra siklus secara klasikal siswa belum tuntas belajar. Karena baru 14 siswa yang memperoleh nilai $\geq 75$ atau hanya sebesar $43.75 \%$ yang mencapai kriteria ketuntasan minimal (KKM).

Sehingga, masih terdapat 18 dari 32 siswa yang belum tuntas belajar. Hasil tersebut lebih kecil dari persentase ketuntasan klasikal dalam proses pembelajaran PKn yang dikehendaki sebesar $80 \%$.

Berdasarkan kenyataan-kenyataan di atas, peneliti dibantu oleh teman sejawat melakukan kajian dan telaah yang akan dipergunakan sebagai dasar pertimbangan memilih strategi pembelajaran yang tepat, dalam upaya melakukan tindakan perbaikan pembelajaran PKN. Setelah berdiskusi dan mempertimbangkan berbagai alasan tersebut, peneliti memilih model pembelajaran Jigsaw. Model ini akan dipergunakan dalam PTK yang akan dilaksanakan pada saat berlangsungnya proses pembelajaran di kelas VI.A SD Negeri 64/IV Kota Jambi, yang diharapkan dapat meningkatkan hasil belajar PKN siswa di kelas tersebut.

Seluruh rangkaian PKN tersebut selanjutnya dibagi menjadi beberapa tahapan, yang sering disebut dengan siklus. Penerapan siklus merupakan bagian dari

tahapan sebuah PTK yang bertujuan untuk mendapatkan data penelitian.

\section{Siklus I \\ Tahap Perencanaan}

Pada tahap ini peneliti mempersiapkan perangkat pembelajaran yang terdiri dari rencana pelajaran 1 , sial tes formatif I dan alat-alat pengajaran yang mendukung. Selain itu juga dipersiapkan lembar observasi pengolahan Model Jigsaw, dan lembar observasi aktifitas guru dan peserta didik.

\section{Tahap kegiatan dan pelaksanaan}

Pelaksanaan kegiatan belajar mengajar untuk siklus I dilakasanakan pada tanggal 2 Maret 2017 di kelas VI.A dengan jumlah peserta didik 32 peserta didik. Pelaksanaan metode pembelajaran kooperatif Tipe Jigsaw melalui tahapan sebagai berikut : (1) Pelaksanaan pembelajaran, (2) Diskusi kelompok, (3) Tes, (4) Penghargaan kelompok, (5) Menentukan nilai individual dan kelompok. Adapun proses belajar mengajar mengacu pada rencana pelajaran yang telah dipersiapkan.

Pengamatan (observasi) dilaksanakan bersamaan dengan pelaksanaan dengan pelaksanaan belajar mengajar. Pada akhir proses belajar mengjaar peserta didik diberi tes formatif I dengan tujuan untuk mengetahui tingkat keberhasilan peserta didik dalam proses belajar mengajar yang telah dilakukan. Adapun data hasil penelitian pada siklus I adalah sebagi berikut:

Tabel 4. Pengelolaan Pembelajaran Pada Siklus I

\begin{tabular}{llcc}
\hline \multirow{2}{*}{ No. Aspek Yang diamati } & \multicolumn{2}{c}{ Penilaian } & \multirow{2}{*}{ Rata-Rata } \\
\cline { 2 - 3 } & P1 & \\
Pengamatan KBM & 1 & 1 \\
A. Pendahuluan & 3 & 2 \\
1. Memotivasi peserta didik & 2.5 & 2 \\
2. Menyampaikan tujuan pembelajaran & 1 & 2 \\
3. Menghubungkan dengan pelajaran sebelumnya & 1.5 \\
4. Mengatur peserta didik dalam kelompok-kelompok belajar & 1 & 2 \\
B. Kegiatan inti & 2 & 1,5 \\
1. Mempresentasikan langkah-langkah metode pembelajaran kooperatif & 1 & 2
\end{tabular}




$\begin{array}{llrrr} & \text { 4. Mengawasi setiap kelompok secara bergiliran } & 1 & 3 & 2 \\ & \text { 5. Memberikan bantuan kepada kelompok yang mengalami kesulitan } & 1 & 2 \\ \text { C. Penutup } & 2 & 2 \\ \text { 1. Membimbing peserta didik membuat rangkuman } & 2 & 2 \\ & \text { 2. Memberikan evaluasi } & 2 & 2 \\ \text { II. Pengelolaan Waktu } & 2 & 2 & 2 \\ & \text { Antusiasme Kelas } & 2 & 2 \\ \text { III. } 1 . \quad \text { Peserta didik antusias } & 2 & 3 \\ \\ \text { Jumlah } 2 . \quad \text { Guru antusias }\end{array}$

Keterangan:

\begin{tabular}{ll}
\hline Nilai & Kriteria \\
\hline 1 & Tidak Baik \\
2 & Kurang Baik \\
3 & Cukup Baik \\
4 & Baik \\
\hline
\end{tabular}

Berdasarkan tabel di atas aspek-aspek yang mendapatkan kriteria kurang baik adalah untuk kegitan pendahulun di dapat no.3 dan 4 dengan nilai kurang. Selanjutnya pada kegiatan Inti yang mendapat nilai kurang baik adalah no. urut 1,2,3,4,dan 5. Untuk kegiatan penutup nilai kurang bai no. 1 dan 2. dan untuk pengelolaan waktu guru mengajar juga mendapat nilai kurang baik. Aspek yang diamamti nilai kurang baik antara skor nilai yang diperoleh antara $1.5 \mathrm{~s} / \mathrm{d} 2$. Berdasarkan dari hasil pengelolaan pembelajaran guru tersebut aspek yang mendapat nilai kurang baik di atas, merupakan suatu kelemahan yang terjadi pada siklus I dan akan dijadikan bahan kajian untuk refleksi dan revisi yang akan dilakukan pada siklus II.

Berikutnya dalah rekapitulasi hasil tes formatif peserta didik seperti terlihat pada tabel berikut:

Tabel 5. Hasil Analisis Tes Evaluasi Siswa Siklus I SD Negeri 64/IV Kota Jambi Tahun Pelajaran 2016/2017

\begin{tabular}{|c|c|c|c|c|c|c|c|c|c|c|}
\hline \multirow[t]{2}{*}{ No } & \multirow[t]{2}{*}{ Nama } & \multicolumn{5}{|c|}{ Nomor Soal } & \multirow{2}{*}{ Jml Skor } & \multirow{2}{*}{ Daya Serap \% } & \multicolumn{2}{|c|}{ Ketuntasan } \\
\hline & & 1 & 2 & 3 & 4 & 5 & & & Ya & Tidak \\
\hline 1 & Alfaredho & 2 & 2 & 1 & 1 & 1 & 70 & $70 \%$ & & $\mathrm{v}$ \\
\hline 2 & Andi Raihan & 2 & 2 & 2 & 1 & 1 & 80 & $80 \%$ & v & \\
\hline 3 & Andreas Manik & 2 & 1 & 1 & 2 & 2 & 80 & $80 \%$ & v & \\
\hline 4 & Audy Anggraini & 1 & 1 & 2 & 2 & 2 & 80 & $80 \%$ & v & \\
\hline 5 & Balqis Felisyalini & 2 & 2 & 1.5 & 1 & 1 & 75 & $75 \%$ & v & \\
\hline 6 & Benyamin.P & 2 & 1.5 & 1 & 1 & 2 & 75 & $75 \%$ & $\mathrm{v}$ & \\
\hline 7 & Dara Maya & 1 & 1 & 2 & 2 & 2 & 80 & $80 \%$ & v & \\
\hline 8 & Desta Bayu P. & 1 & 1 & 1 & 1 & 0 & 40 & $40 \%$ & & $\mathrm{v}$ \\
\hline 9 & Dini Andriani & 2 & 2 & 1 & 1 & 1 & 70 & $70 \%$ & & $\mathrm{v}$ \\
\hline 10 & Duwanti Maharani & $\overline{1}$ & 1 & 2 & 2 & 2 & 80 & $80 \%$ & v & \\
\hline 11 & Enji Avrilaysa & 2 & 1 & 1 & 1 & 1 & 60 & $60 \%$ & & v \\
\hline 12 & Izky Wardaniah & 2 & 2 & 2 & 2 & 1 & 90 & $90 \%$ & v & \\
\hline 13 & Josef Martinus & 2 & 2 & 1 & 1 & 2 & 80 & $80 \%$ & $\mathrm{v}$ & \\
\hline 14 & Julius Martinus & 1 & 1 & 2 & 2 & 1.5 & 75 & $75 \%$ & $\mathrm{v}$ & \\
\hline 15 & Kamila & 1 & 1 & 1 & 1 & 1 & 50 & $50 \%$ & & v \\
\hline 16 & Dwi Carel & 2 & 1 & 1 & 1 & 1 & 60 & $80 \%$ & v & \\
\hline 17 & M.Fadil Pratama & 2 & 2 & 1 & 0 & 0.5 & 55 & $55 \%$ & & v \\
\hline 18 & M.Febrian & 1 & 0.5 & 1 & 1 & 1.5 & 50 & $50 \%$ & & $\mathrm{v}$ \\
\hline 19 & M.Rifki Januarda & 1 & 1 & 1 & 2 & 1 & 60 & $60 \%$ & & v \\
\hline 20 & Mafaza Karima & 1 & 1.5 & 2 & $\overline{2}$ & 2 & 85 & $85 \%$ & v & \\
\hline 21 & M.Rifky & 1 & 1 & 2 & 2 & 2 & 80 & $80 \%$ & $\mathrm{v}$ & \\
\hline 22 & M.Naufal & 2 & 2 & 2 & 1.5 & 1 & 85 & $85 \%$ & v & \\
\hline 23 & M.Valenzo & 1.5 & 2 & 2 & 1 & 2 & 85 & $85 \%$ & v & \\
\hline 24 & Nadia Rahmayanti & 1 & 2 & 1 & 2 & 1.5 & 75 & $75 \%$ & v & \\
\hline 25 & Puspita Indriani & 2 & 1 & 1 & 1 & 1 & 60 & $60 \%$ & & v \\
\hline 26 & Puti Jelita Zahara & 2 & 1 & 1 & 2 & 2 & 80 & $80 \%$ & v & \\
\hline 27 & Roro Refa & 2 & 2 & 1 & 1 & 1 & 80 & $80 \%$ & $\mathrm{v}$ & \\
\hline 28 & S.M.Fadlan & 1 & 1 & 2 & 2 & 2 & 80 & $80 \%$ & v & \\
\hline 29 & Septi Yuliana & 1.5 & 1 & 1.5 & 1.5 & 2 & 75 & $75 \%$ & v & \\
\hline 30 & Shella Putri & 1 & 1 & 1 & 1 & 1 & 50 & $50 \%$ & & v \\
\hline 31 & Stepanus & 2 & 2 & 1 & 1 & 1.5 & 75 & $75 \%$ & v & \\
\hline 32 & Talitha & 2 & 1.5 & 2 & 1 & 1 & 75 & $75 \%$ & $\mathrm{v}$ & \\
\hline & Jumlah Skor & & & & & & 2295 & & 22 & 10 \\
\hline & Nilai Rata - Rata Perkelas & & & & & & 71.72 & Cukup & $68.75 \%$ & $31.25 \%$ \\
\hline
\end{tabular}


Tabel 6. Rekapitulasi Hasil Tes Formatif Pada Siklus I

\begin{tabular}{clc}
\hline No. & \multicolumn{1}{c}{ Uraian } & Hasil Siklus I \\
\hline 1. & Nilai rata-rata tes formatif & 71,72 \\
2. & Jumlah peserta didik yang tuntas belajar & 22 \\
3. & Persentase ketuntasan belajar & $68.75 \%$ \\
\hline
\end{tabular}

Dari tabel di atas dapat dijelaskan bahawa dengan menerapkan metode pembelajaran kooperatif Tipe Jigsaw diperoleh nilai rata-rata prestasi belajar peserta didik adalah 71,72 dan ketuntasan belajar mencapai 68,75\% atau ada 22 peserta didik dari 32 peserta didik sudah tuntas belajar. Hasil tersebut menunjukkan bahwa pada siklus pertama secara klasikal peserta didik belum tuntas belajar, karena peserta didik yang memperoleh nilai $\geq 75$ hanya sebesar $68,75 \%$ lebih kecil dari presentase ketuntasan yang dikehendaki yaitu sebesar $80 \%$. Hal ini disebabkan karena peserta didik masih merasa baru dan belum mengerti apa yang dimaksudkan dan digunakan guru dengan menerapkan Model pembelajaran kooperatif Tipe Jigsaw.

\section{Refleksi}

Dalam pelaksanaan kegiatan belajar mengajar diperoleh informasi dari hasil pengamatan sebagai berikut :

1) Guru kurang maksimal dalam memotivasi peserta didik dan dalam menyampaikan tujuan pembelajaran.

2) Guru kurang maksimal dalam pengelolaan waktu

3) Peserta didik kurang aktif selama pembelajaran berlangsung

\section{Siklus II}

\section{Tahap perencanaan}

Pada tahap ini peneliti mempersiapkan perangkat pembelajaran yang terdiri dari rencana pelajaran 2 , soal tes formatif 2 dan alat-alat pengajaran yang mendukung. Selain itu juga dipersiapkan lembar observasi pengelolaan metode pembelajaran kooperatif Tipe Jigsaw dan lembar observasi guru dan peserta didik.

\section{Tahap kegiatan dan pelaksanaan}

Pelaksanaan kegiatan belajar mengajar untuk siklus II dilaksanakan pada tanggal 10 Maret 2017 di kelas VI.A dengan jumlah peserta didik 32 peserta didik. Pelaksanan Model Jigsaw melalui tahapan sebagai berikut; (1) Pelaksanaan pembelajran, (2) Diskusi klompok, (3) Tes, (4) Penghargaan kelompok, (5) Menentukan nilai individual dan kelompok. Adapun proses belajar mengajar mengacu pada rencana pelajaran dengan memperhatikan revisi pada siklus I, sehingga kesalahan atau kekurangan pada siklus I tidak terulang lagi pada siklus II.

Pengamatan (observasi) dilaksanakan bersamaan dengan pelaksanaan belajar mengajar. Pada akhir proses belajar mengajar peserta didik diberi tes formatif II dengan tujuan untuk mengetahui tingkat keberhasilan peserta didik dalam proses belajar mengajar yang telah dilakukan. Instrument yang digunakan adalah tes formatif II. Adapun data hasil penelitian pada siklus II adalah sebagi berikut:

Tabel 7. Pengelolaan Pembelajaran Pada Siklus II

\begin{tabular}{|c|c|c|c|c|}
\hline No. & Aspek Yang diamati & \multicolumn{2}{|c|}{ Penilaian } & Rata-Rata \\
\hline \multirow{13}{*}{ I. } & $\begin{array}{l}\text { Pengamatan KBM } \\
\text { A. Pendahuluan }\end{array}$ & & & \\
\hline & 1. Memotivasi peserta didik & 4 & 4 & 4 \\
\hline & 2. Menyampaikan tujuan pembelajaran & 3 & 4 & 3.5 \\
\hline & 3. Menghubungkan dengan pelajaran sebelumnya & 3 & 4 & 3,5 \\
\hline & 4. Mengatur peserta didik dalam kelompok-kelompok belajar & 3 & 3 & 3 \\
\hline & B. Kegiatan inti & & & \\
\hline & 1. Mempresentasikan langkah-langkah metode pembelajaran kooperatif & 3 & 4 & 3.5 \\
\hline & 2. Membimbing peserta didik melakukan kegiatan & 4 & 4 & 4 \\
\hline & 3. Melatih keterampilan kooperatif & 3 & 3 & 3 \\
\hline & 4. Mengawasi setiap kelompok secara bergiliran & 3 & 4 & 3,5 \\
\hline & $\begin{array}{l}\text { 5. Memberikan bantuan kepada kelompok yang mengalami kesulitan } \\
\text { C. Penutup }\end{array}$ & 3 & 4 & 3,5 \\
\hline & 1. Membimbing peserta didik membuat rangkuman & 4 & 4 & 4 \\
\hline & 2. Memberikan evaluasi & 3 & 3.5 & 3.5 \\
\hline \multirow[t]{2}{*}{ II. } & Pengelolaan Waktu & 3 & 3 & 3 \\
\hline & Antusiasme Kelas & & & \\
\hline \multirow[t]{2}{*}{ III. } & 1. Peserta didik antusias & 3 & 3 & 3 \\
\hline & 2. Guru antusias & 4 & 4 & 4 \\
\hline \multicolumn{2}{|c|}{ Jumlah } & 46 & 51 & 48.5 \\
\hline
\end{tabular}

Keterangan:

\begin{tabular}{ll}
\hline Nilai & Kriteria \\
\hline 1 & Tidak Baik \\
2 & Kurang Baik \\
3 & Cukup Baik \\
4 & Baik \\
\hline
\end{tabular}


Dari tabel di atas, tanpak aspek-aspek yang diamati pada kegiatan belajar mengajar (siklus II) yang dilaksanakn oleh guru dengan menerapkan metode pembelajarn kooperatif Tipe Jigsaw mendapatkan penilaian yang baik dari pengamat. Maksudnya dari seluruh penilaian tidak terdapat nilai kurang dan cukup hanya 4 aspek sedangkan 10 aspek lainya mencapai nilai baik dari 14 aspek yang diamati. Namun demikian penilaian tesebut belum merupakan hasil yang optimal, untuk itu ada beberapa aspek yang perlu mendapatkan perhatian untuk penyempurnaan penerapan pembelajaran selanjutnya. Aspek-aspek tersebut adalah memotivasi peserta didik, melatih keterampilan kooperatif, dan pengelolaan waktu.

Dengan penyempurnaan aspek-aspek I atas alam penerapan metode pembelajarn kooperatif Tipe Jigsaw diharapkan peserta didik dapat menyimpulkan apa yang telah mereka pelajari dan mengemukakan pendapatnya sehingga mereka akan lebih memahami tentang apa yang telah mereka lakukan. Berikutnya adalah rekapitulasi hasil tes formatif peserta didik terlihat pada tabel berikut:

Tabel 8. Hasil Analisis Tes Evaluasi Siswa Siklus II Materi ASEAN SD Negeri 64/IV Kota Jambi Tahun Pelajaran 2016/2017

\begin{tabular}{|c|c|c|c|c|c|c|c|c|c|c|}
\hline \multirow[t]{2}{*}{ No } & \multirow[t]{2}{*}{ Nama } & \multicolumn{5}{|c|}{ Nomor Soal } & \multirow{2}{*}{ Jml Skor } & \multirow{2}{*}{ Daya Serap \% } & \multicolumn{2}{|c|}{ Ketuntasan } \\
\hline & & 1 & 2 & 3 & 4 & 5 & & & Ya & Tidak \\
\hline 1 & Alfaredho & 2 & 2 & 2 & 1.5 & 1 & 85 & $85 \%$ & $\mathrm{v}$ & \\
\hline 2 & Andi Raihan & 2 & 2 & 2 & 2 & 1 & 90 & $80 \%$ & v & \\
\hline 3 & Andreas Manik & 2 & 1 & 2 & 2 & 2 & 90 & $80 \%$ & $\mathrm{v}$ & \\
\hline 4 & Audy Anggraini & 1 & 2 & 2 & 2 & 2 & 90 & $80 \%$ & $\mathrm{v}$ & \\
\hline 5 & Balqis Felisyalini & 2 & 2 & 2 & 1 & 1.5 & 85 & $85 \%$ & $\mathrm{v}$ & \\
\hline 6 & Benyamin.P & 2 & 2 & 1 & 1 & 2 & 90 & $75 \%$ & v & \\
\hline 7 & Dara Maya & 1 & 1 & 2 & 2 & 2 & 80 & $80 \%$ & $\mathrm{v}$ & \\
\hline 8 & Desta Bayu P. & 2 & 2 & 2 & 1 & 1 & 80 & $80 \%$ & $\mathrm{v}$ & \\
\hline 9 & Dini Andriani & 2 & 2 & 2 & 1 & 1 & 90 & $80 \%$ & $\mathrm{v}$ & \\
\hline 10 & Duwanti Maharani & 1 & 1.5 & 2 & 2 & 2 & 85 & $85 \%$ & $\mathrm{v}$ & \\
\hline 11 & Enji Avrilaysa & 2 & 1.5 & 1 & 1 & 1 & 80 & $75 \%$ & $\mathrm{v}$ & \\
\hline 12 & Izky Wardaniah & 2 & 2 & 2 & 2 & 1.5 & 9.5 & $95 \%$ & $\mathrm{v}$ & \\
\hline 13 & Josef Martinus & 2 & 2 & 1 & 1 & 2 & 80 & $80 \%$ & v & \\
\hline 14 & Julius Martinus & 1 & 1 & 2 & 2 & 2 & 80 & $80 \%$ & $\mathrm{v}$ & \\
\hline 15 & Kamila & 1 & 2 & 2 & 1 & 1 & 70 & $70 \%$ & & $\mathrm{v}$ \\
\hline 16 & Dwi Carel & 2 & 2 & 1 & 1 & 2 & 80 & $80 \%$ & $\mathrm{v}$ & \\
\hline 17 & M.Fadil Pratama & 2 & 2 & 1 & 1 & 1.5 & 75 & $75 \%$ & $\mathrm{v}$ & \\
\hline 18 & M.Febrian & 2 & 1 & 2 & 1 & 2 & 80 & $80 \%$ & $\mathrm{v}$ & \\
\hline 19 & M.Rifki Januarda & 1 & 2 & 2 & 2 & 2 & 90 & $90 \%$ & $\mathrm{v}$ & \\
\hline 20 & Mafaza Karima & 1 & 2 & 2 & 2 & 2 & 90 & $90 \%$ & $\mathrm{v}$ & \\
\hline 21 & M.Rifky & 1 & 1 & 2 & 2 & 2 & 80 & $80 \%$ & $\mathrm{v}$ & \\
\hline 22 & M.Naufal & 2 & 2 & 2 & 2 & 1 & 90 & $90 \%$ & $\mathrm{v}$ & \\
\hline 23 & M.Valenzo & 1.5 & 2 & 2 & 1 & 2 & 85 & $85 \%$ & $\mathrm{v}$ & \\
\hline 24 & Nadia Rahmayanti & 2 & 2 & 1 & 2 & 2 & 90 & $90 \%$ & v & \\
\hline 25 & Puspita Indriani & 2 & 2 & 2 & 1 & 1 & 80 & $80 \%$ & $\mathrm{v}$ & \\
\hline 26 & Puti Jelita Zahara & 2 & 1 & 1 & 2 & 2 & 80 & $80 \%$ & $\mathrm{v}$ & \\
\hline 27 & Roro Refa & 2 & 2 & 2 & 1 & 1 & 80 & $90 \%$ & $\mathrm{v}$ & \\
\hline 28 & S.M.Fadlan & 1 & 1 & 2 & 2 & 2 & 80 & $80 \%$ & $\mathrm{v}$ & \\
\hline 29 & Septi Yuliana & 2 & 1 & 2 & 2 & 2 & 90 & $90 \%$ & $\mathrm{v}$ & \\
\hline 30 & Shella Putri & 2 & 2 & 1 & 1 & 1 & 70 & $70 \%$ & & $\mathrm{v}$ \\
\hline 31 & Stepanus & 2 & 2 & 1 & 1 & 1.5 & 80 & $80 \%$ & $\mathrm{v}$ & \\
\hline 32 & Talitha & 2 & 1.5 & 2 & 1 & 1 & 80 & $80 \%$ & v & \\
\hline & & Jum & ah Sk & & & & 2584.5 & & 30 & 2 \\
\hline & & Nila & Rata - & & erke & & 80.77 & Cukup & $93.75 \%$ & $0.25 \%$ \\
\hline
\end{tabular}

Tabel 9. Rekapitulasi Hasil Tes Formatif Pada Siklus II

$\begin{array}{cl}\text { No. } & \text { Uraian } \\ \text { 1. } & \text { Nilai rata-rata tes formatif } \\ \text { 2. } & \text { Jumlah siswa yang tuntas belajar } \\ \text { 3. } & \text { Persentase ketuntasan belajar }\end{array}$

Dari tabel diatas diperoleh nilai rata-rata prestasi belajar peserta didik adalah $78,50 \%$ dengan ketuntasan belajar mencapai $85,00 \%$ atau ada 32 peserta didik dari 32 peserta didik sudah tuntas belajar. Maka secara klasikal ketuntasan belajar yang telah tercapai sebesar $85,00 \%$ (termasuk kategori tuntas). Hasil pada siklus II ini mengalami peningkatan lebih baik dari siklus I. Adanya peningkatan hasil belajar pada siklus II ini di pengaruhi oleh adanya peningkatan kemampuan guru dalam menerapkan Model Jigsaw sehingga peserta didik menjadi lebih terbiasa dengan pembelajaran seperti ini 
sehingga peserta didik lebih mudah dalam memahami materi yang telah diberikan.

\section{Refleksi}

Pada tahap ini akan dikaji apa yang telah terlaksana dengan baik maupun yang masih kurang baik dalam proses belajar mengajar dengan penerapan metode pembelajaran kooperatif Tipe Jigsaw. Dari datadata yang telah diperoleh dapat diuraikan sebagi berikut

1) Selama proses belajar mengajar guru telah mekasanakan semua pembeljaran dengan baik. Meskipun ada beberapa aspek yang belum sempurna, tetapi presentase pelaksanaanya untuk masing-masing aspek cukup besar.

2) Berdasarkan data hasil pengamatan diketahui bahwa peserta didik aktif selama proses belajar mengajar berlangsung.

3) Kekurangan pada siklus-siklus sebeelumnya sudah mengalami perbaikan dan peningkatan sehingga menjadi lebih baik.

4) Hasil belajar peserta didik paa siklus II mencapai ketuntasan.

\section{Pembahasan}

\section{Ketuntasan hasil belajar peserta didik}

Melalui hasil penelitian ini menunjukkan bahawa Model Jigsaw memiliki dampak positif dalam meningkatkan hasil belajar peserta didik. Hal ini dapat dilihat dari semakin mantapnya pemahaman peserta didik terhadap materi yang disampaikan guru (ketuntasan belajar meningkat dari pra siklus, siklus I, dan II) yaitu masing-masing 50,00\%, 65,00\%, dan $85,00 \%$. Pada siklus II ketuntasan belajar peserta didik secara klasikal telah tercapai. Pada siklus II ketuntasan belajar peserta didik secara klasikal telah tercapai Kemampuan Guru Dalam Mengelola Pembelajaran.

Berdasarkan analisis data, diperoleh aktifitas peserta didik dalam proses belajar mengajar dengan mennerapkan metode pembelajaran kooperatif Tipe Jigsaw dalam setiap siklus mengalami peningkatan. Hal ini berdampak positif terhadap hasil belajar peserta didik yaitu dapat ditunjukkan dengan meningkatnya nilai ratarata peserta didik pada setiap siklus yang terus menglami peningkatan.

\section{Grafik 4.3 Pencapaian KKM Klasikal}

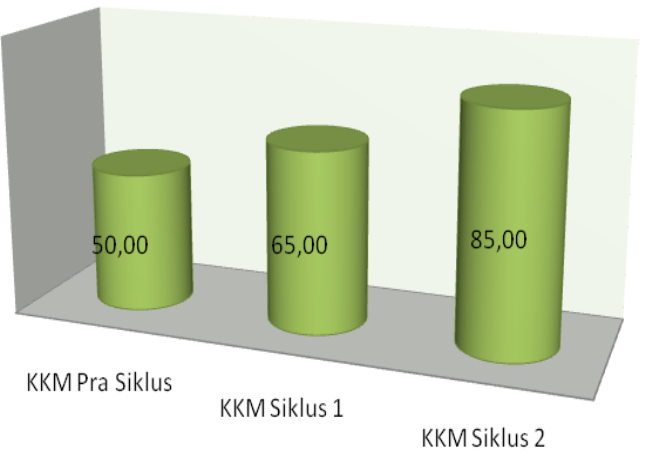

\section{Kemampuan Guru dalam Mengelola Pembelajaran}

Berdasarkan analisis data, diperoleh aktivitas peserta didik dalam proses pembelajaran dengan pemberian tugas dalam setiap siklus mengalami peningkatan. Hal ini berdampak positif terhadap proses mengingat kembali materi pelajaran yang telah diterima selama ini, yaitu dapat ditunjukkan dengan meningkatnya nilai rata-rata peserta didik pada setiap siklus yang terus mengalami peningkatan. Aktivitas Guru dan Peserta didik Dalam Pembelajaran.

Berdasakan analisi data, diperoleh aktifitas peserta didik dalam proses pembelajran PKN dengan Model Jigsaw yang paling dominan adalah bekerja dengan sesama anggota kelompok, mendengarkan/ memperhatikan penjelasan guru dan diskusi antar peserta didik /antara peserta didik dengan guru.

Sedangkan untuk aktifitas guru selama pembelajaran telah melaksanakan langkah-langkah kegiatan belajar mengajar dan menerapkan pengajaran konstektual model pengajaran berbasis maslah dengan baik. Hal ini terlihat dari aktivitas guru yang muncul, diantaranya aktivitas membimbing dan mengamati peserta didik dalam menemukan konsep, menjelaskan materi yang sulit, memberi umpan balik/ evaluasi/ tanya jawab dimana prosentase untuk aktivitas di atas cukup besar.

\section{SIMPULAN}

Berdasarkan hasil penelitian yang telah dipaparkan selama dua siklus, hasil seluruh pembahasan serta analisis yang telah dilakukan dapat disimpulkan sebagai berikut : Model Jigsaw dapat meningkatkan kualitas pembelajaran PKN dan Model Jigsaw memiliki dampak positif dalam meningkatkan hasil belajar peserta didik yang ditandai dengan peningkatan ketuntasan belajar peserta didik dalam setiap siklus, yaitu pra siklus $(50,00 \%)$, siklus I $(65,00 \%)$, sklus II (85,00\%).

\section{DAFTAR PUSTAKA}

Arikunto, S. 2007. Penelitian Tindakan Kelas. Jakarta : PT. Bumi Aksara

Abdurrahman, M. 2009. Pendidikan Bagi Anak Berkesulitan Belajar. Jakarta : Rineka Cipta.

Agus Suprijono.2012. Cooperative Learning Teori dan aplikasi PAIKEM. Yogyakarta:Pustaka Belajar.

Effendi,mawardi.2010. istilah-istilah dalam praktik mengajar dan pembelajaran.padang: UNP press

Hamalik, O. 2009. Pendekatan Baru Strategi Belajar Mengajar Berdasarkan CBSA. Jakarta: Sinar Baru Algensindo.

Hariyanto, Suryono. 2012. Belajar Dan Pembelajaran. Bandung: PT. Remaja Rosdakarya.

Ibrahim, dkk. 2010. Model-Model Pembelajaran Asesmen, Media, Dan RPP SD. Palembang : Universitas Sriwijaya.

Kusumah, W dan Dedi Dwitagama. 2009. Mengenal Penelitian Tindakan Kelas. Jakarta : Rineka Cipta.

Margono, S. 2004. Metodologi Penelitian Pendidikan. Jakarta : Rineka Cipta.

Martoyo, Susilo. 2007. Manajemen Sumber Daya Manusia,: Yogyakarta: BPFE

Nana, Sudjana. 2009. Penilaian Hasil Proses Belajar Mengajar. Bandung: PT. Remaja Rosdakarya. 
Purwanto, M. 2004. Prinsip-prinsip dan teknik Evaluasi Pengajaran. Bandung: Remaja Rosdakarya

Rusman.2012. Model-model pembelajaran. Jakarta: PT raja grafindo persada.

Sudjana, N. 2006. Penilaian Hasil Proses Belajar Mengajar. Bandung : Remaja Rosdakarya.

Sagala, S. 2010. Konsep dan Makna Pembelajaran. Bandung : Alfabeta.

Slameto. 2003. Belajar dan Faktor-Faktor yang Mempengaruhinya. Jakarta : Rineka Cipta.

Trianto. 2010. Mendesain Model Pembelajaran InovatifProgesif. Jakarta : Kencana Prenada Media Group.

Wahab, A. A. 2008. Metode dan Model-model Mengajar. Bandung: Alfabeta.

Wena,made. 2012. Strategi pembelajran inovstif kontemporer. Jakarta:bumi aksara

UU No. 20 Tahun 2003. Depdiknas 2006. 